\title{
التكبر مفهومه واسبابه وعلاجه في القران الكريم والسنة المطهرة
}

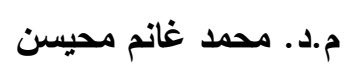

\section{المقدمة}

خلق الله سبحانه وتعالى الانسان وكرمـه ، وفضله على كثير من مخلوقاته ، ومن دلائل

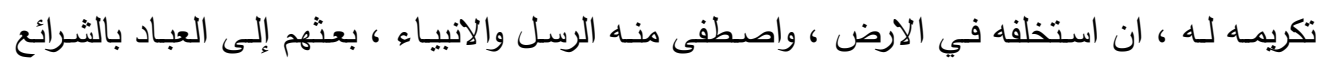

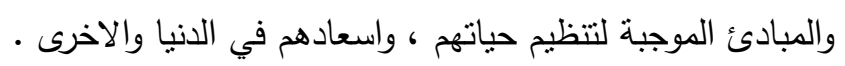

لكن اغلب البشر تمردوا على النظم الالهية ، وتشريعها الهادف البناء ، فتاهوا في مجاهل

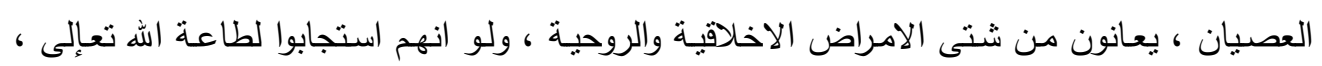
وساروا على هدي نظمه ودساتيره ، لسعدوا وفازوا فوزاً عظيما.

ومن الامراض الاخلاقية الخطيرة التي شاعت في الاوساط الاجتماعية ، وسرت عدواها ، وطغت مضاعفاتها على المجتمع هو (التكبر ) •

فالتكبر هذه الصفة الذميمة في نظر العلم والدين ، تعتبر من السيئات الخلقية الكبيرة ، وتعدُ

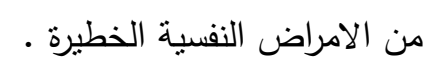
فالمتكبر يظن نفسه انه في مرتبـة الكمال ، واسمى من الاخرين ، وبالتالي سيغلق ابواب

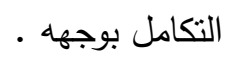

إن الثـريعة الاسـلامية هي خاتمـة الثـرائع والاديـان ، لذلك تتاولت ظـاهرة التكبر ، مبينـة

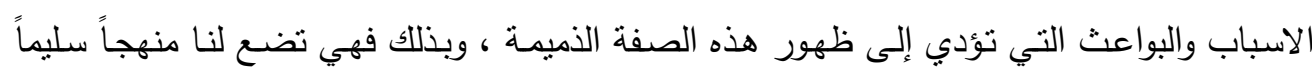

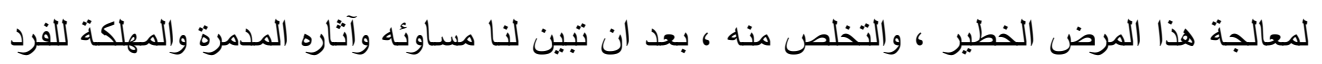
- المجتمع

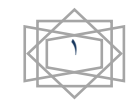


لللك إخترت أن ابحث هذا الموضوع من خلال الإيات الكريمة ، والأحاديث الثريفة التي تتاولته ، لبيان مفهومه وأسبابه وطرائق معالجته .

وقد جاء البحث على ثلاثة مباحث تسبقها المقدمة وتليها الخاتمة التي بينت فيها أهم النتائج الني توصل اليها البحث .

تتاولت في المبحث الاول : مفهوم التكبر في اللغة والاصطلاح ، ثم بينت اهم الاسباب والبواعث التي تؤدي إلى ظهور التكبر •

أما المبحث الثاني فكان دراسة لبعض الايات القرانية التي حذرت من التكبر ونهت عنه ، مشيرا إلى اقسام التكبر وانواعه . التحبن

وتتاولت في المبحث الثالث أهم الروايات التي جاءت في باب الكبر ، في الجوامع الحديثية .

وأخيراً أسأل اله سبحانه وتعإلى أن يوفقني لخدمة كتابه المجيد ، وسنة رسوله الكريم (صلى اله عليه واله وسلم) ، وأن يغفر لي كل وهم وقعت فيه ، إنه سميع مجيب والحمد لله رب العالمين . 


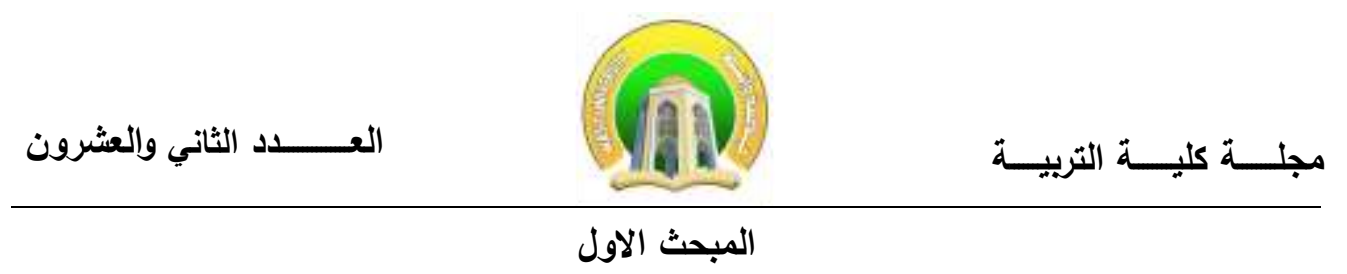

\section{مفهوم التكبر واسبابه :}

التكبر في اللغة :

الكبر والتكبر والاستكبار تتقارب(') ، قال ابن منظور (ت ال الهـ) :(تكبر واستكبر وتكابر ،

وقيل تكبر من الكبر ، والكبير في صفة اله تعإلى ، والكبرياء عظمـة اله ، قال ابن الاثير : من اسماء اله تعإلى المتكبر والكبير ، أي العظيم ذو الكبرياء ، والكبرياء العظمة والملك ، وقيل : عبارة

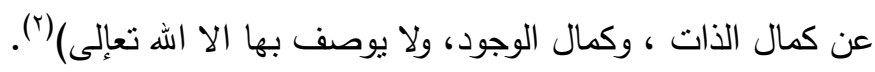
وقد ورد الكبر بمعنى الاستكبار على الله سبحانه وتعاللى ، وجحود الحق في ثمانية وخمسين

هو حالة تدعو إلى الاعجاب بالنفس ، والتعاظم على الغير ، بالقول أو الفعل، وهو من اخطر الامراض الخلقية واشدها فتكاً في الانسان ، وادعاها إلى مقت الناس له وازدرائهم بـه ، ونفرتهم منه (؟) اخطر)

فقد روى مسلم (ت آTrه) باسناده عن عبد الله بن مسعود ، قال : قال رسول الله (صلى الله عليه

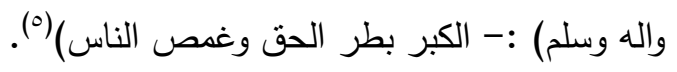

وروى الصـدوق (ت ایمبهـ) باسـاده عن الامـام الصـادق (عليـه السـلام) قال :- (الكبر أن يغمص الناس ويسفه الحق)(")

بمعنى أن التكبر عبـارة عن غمص حقوق النـاس باحتقارهم ، وترك الحق لتعارضـه مـع اهوائه وغاياته الشخصية .

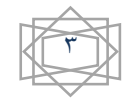


فالمتكبر يعرف بصفتين أحداهما : تحقير الناس ، والثانية عدم رؤية الحق والواقع ـ لأن التكبر من أعظم الحجب التي تسدل على العقل فتؤدي إلى ظلمته ، وكلما كان نفوذ هذه الصفة الذميمة في روح الفرد أقوى كان حرمان العقل من ادراك الحقائق وروئية الواقع أثند .

لذلك فان المتكبرين يقدمون في سلوكهم على أعمال غير عقلانية ، وربما أدى الامر إلى الجنون ، ولقد صرحت الاحاديث بذلك ، واعتبرت التكبر ضرب من الجنون ، فقد روى جابر بن عبد

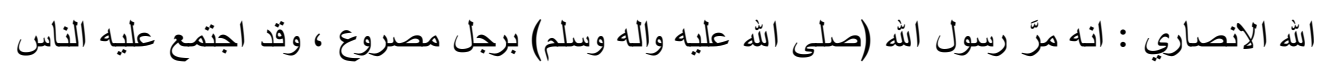

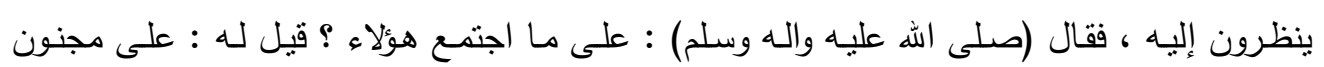
يصرع ، فنظر إليه، فقال : ما هذا بمجنون ، ألا أخبركم بالمجنون حق الجنون ؟ قالوا بلى يارسول هول هولاء الله ، قـال : إنّ المجنون حق الجنون : المنبختر في مشيه ، الناظر في عطفيـه ، المحرك جنبيـه

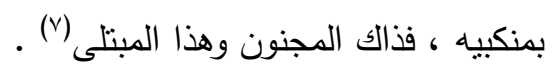

إن المصابين بداء التكبر ينظرون إلى اعمالهم جميعها نظرة الاستحسـان ، ويتوقعون من

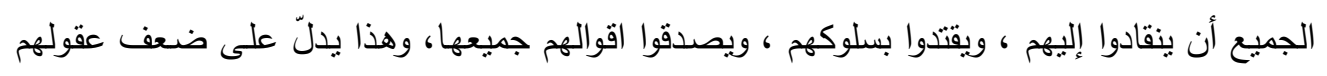

قال الامام علي (عليه السلام) : (اعجاب المرء بنفسه دليل على ضعف عقله)(^). وقال ايضاً : (شر آفة العقل الكبر)(9). وعن الامام الباقر (عليه السلام) قوله :- (ما دخل قلب امرئ شيء من الكبر قط إلا نقص من عقله بقدر مادخل من ذلك قل او كثر)(·'). التكبر ممكن أن يظهر في الطبقات جميعها :-

لا يختص التكبر بطبقة دون اخرى ، ولا بمجتمع دون سواه ، فمن الممكن أن يظهر هذا الداء في الطبقات والامم جميعها ، وانه بظهر في الاغنياء والفقراء ، في البيض والسود ، في القادة و المنقادين 
فعن الامام الصادق (عليه السلام) قوله :- (الكبر قد يكون في شرار الناس من كل جنس)('").

وليس من التكبر أن يهتم الانسان بمظهره الخارجي ، ويوسع على نفسه وعياله في الملبس ، والبس

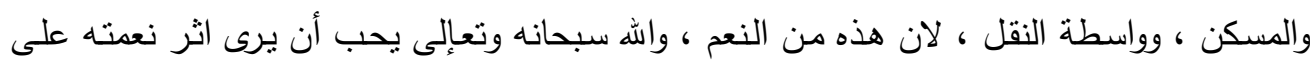

فقد روى الحاكم النيسابوري (ته ـــه) بسنده عن عبد اله بن عمرو ، قال : قلت يارسول اله : من

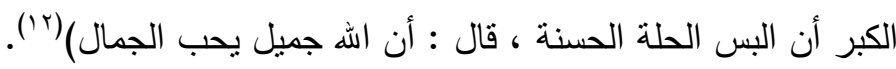

وقال (صلى الله عليه والـه وسلم) ايضـا :- (انه ليس من الكبر ان تحسن راحلتك ورحلك ، ولكن الكبر من سفه الحق وغمص الناس)(r'ا").

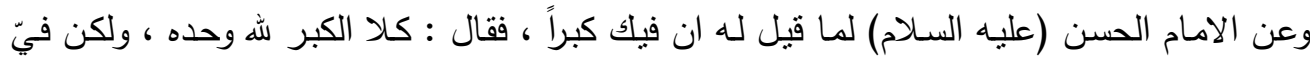

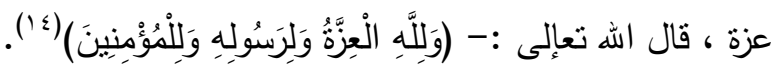

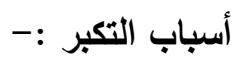

إن المقيـاس الأساسـي والعلمي لنشـوء ظـاهرة التكبر ، هو الاحسـاس بنـوع من الضـفف

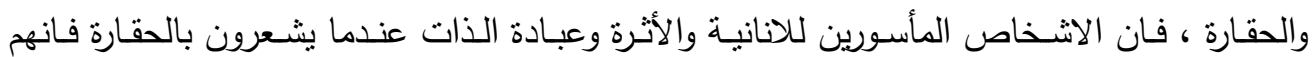

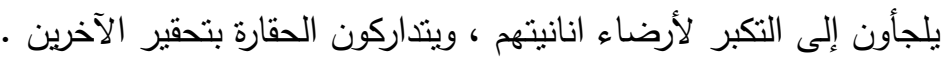
فعن الامام الصادق (عليه السلام) :- (ما من رجل تكبر أو تجبر إلا لذلة وجدها في نفسه)(1). وان الذي يصاب بالتكبر ، وينظر إلى المجتمع بعين الحقارة والذلة ، يواجه بلا ريب رد فعل

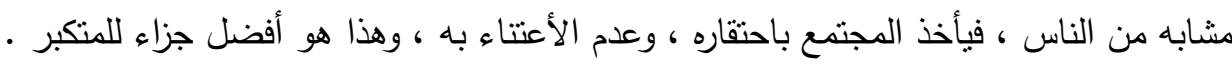
فال الامام علي (عليه السلام) في وصيته لابنه الحسن (عليه السلام) :- (من تكبر على الناس ذل)(17). ثم الذي يبعث المتكبر على التكبر امور اهما :- 
كثير مايكون النسب سبباً وراء تكبر البعض باعتبار أن اباه كان حاكماً ، أو ذا مال ، أو انه كان خيراً او فاضلاً ، فيفتخر بذللك ، ويدعوه إلى التكبر على الآخرين ، وهو بذلك يتكبر بكمال غيره ، على تقدير أن هذه الصفات من الكمالات، فهي كمال لابيه لا لله ، والعاقل لايفتخر بكمال غيره

قال الرسول الكريم (صلى الله عليه واله وسلم) :- (كلكم بنو آدم ، وادم من تراب ، لينتهينَ قوم

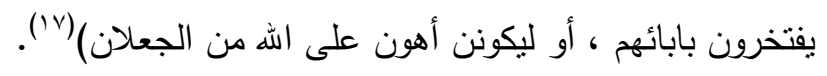

ثم لما كان نظره إلى الاصل كان أصله القريب أولى بالنظر إليه وهو النطفة القذرة النجسة

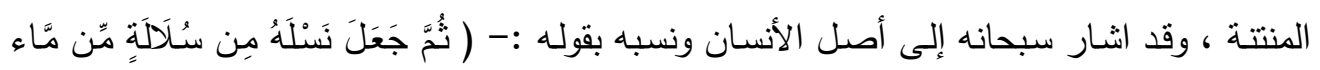
مَّكِينِ (1)

الثاني : الحسن والجمال .

هو صفاء ظاهر البدن بالتتاسب في الصور والاثكال ، فكثيراً مايعجب الانسـان بمسحة

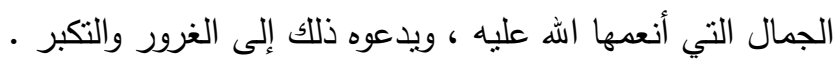
فعن الامام علي (عليه السلام) :- (إعجاب المرء بنفسه دليل على ضعف عقله)(19). لأنه قد افتخر باشياء قد تزول بادنى الأمراض والأسقام ، وما هو في عرضـة الزوال ليس

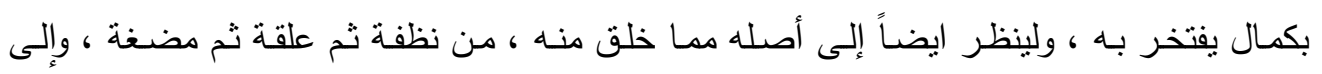
مايصير إليه في القبر من جيفة منتنة .

وقد روى الصدوق باسناده عن الامام الصادق (عليه السلام) ، عن ابيه ، عن جده (عليهم السلام) ، قدام) قال : وقع بين سلمان الفارسي وبين رجل كلام وخصومة ، فقال له الرجل : من انت يا سلمان؟ فقال

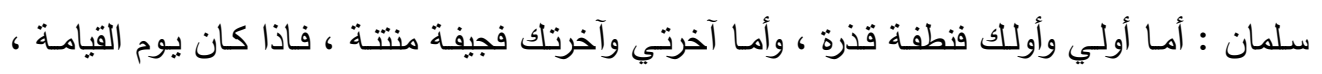
ووضعت الموازين ، فمن نقل ميزانه فهو الكريم ، ومن خفّ ميزانه فهو اللئيم(·r) .

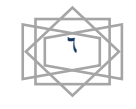


الثالث : الثلم

وهو من الاسباب المهمة التي تدعو إلى التكبر ، فقد ينعم الله سبحانه وتعالىى على الثخص بالنبوغ وسعة المعرفة ، والتفوق على اقرانه ، والجدير به أن يدعوه ذلك إلى التواضع شكراً لله سبحانه وتعإلى على هذه النعمة .

فصاحب العلم لله قدر عظيم عند الله ، وهو مقدر عند المخلوقات جميعها ، قال الرسول (صلى الله عليه واله وسلم) :- ( العالم اذا اراد بعلمه وجه الله عز وجل هابه كل شيء )('اr) . فما اسرع الكبر إلى العلماء ، قال (صلى الله عليه واله وسلم) :- (آفة العلم الخيلاء)(rr) ـ فاذا تكبر العالم وافتخر ، فليعلم ان خطر اهل العلم اكثر من خطر اهل الجهل ، وان اله تعاللى يحتمل من

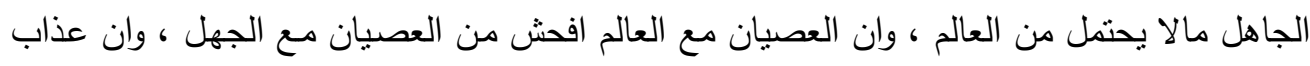

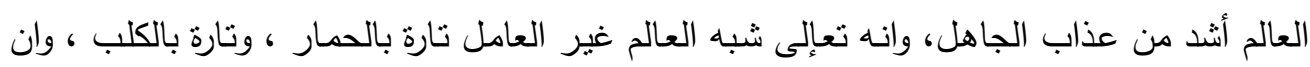
الجاهل أقرب إلى السلامة من العالم لكثرة افاته ، وسوء العاقبة وحسنها أمر لا يعلمه الا الله سبحانه وتعإلى ، فلعل الجاهل أحسن عاقبة من العالم .

فضلاً عن أنَّ الكبرياء رداء الله سبحانه وتعإلى ومختص بـه ، وأن المتكبر ممقوت عند الله تعإلى ، ومعذب في الاخرة ، كما قال تعإلى :- (أليس في جهنم مثوى للمتكبرين)(r(r) . وروي عن الامسام الباقر (عليه السـام) قوله :- (العز رداء الله ، والكبر ازاره ، فمن تتاول شيئًا منهـ أكبه الله في جهنم)(عام) .

فاذا علم المتكبر هذه الامور بعين اليقين ، وتأمل فيها تأملاً صادقاً ، ونظر اليها نظراً دقيقاً

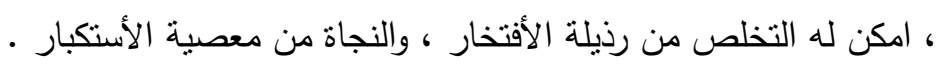

الرابع : القوة والشجاعة .

كثير من الناس من يفتخر بالقوة والثجاعة ، فمن افتخر بها فليعلم ان الذي خلقه هو أثد منه قوة ، وان أدنى العلل والامراض تجعله أعجز من كل عاجز ، وأذل من كل ذليل ، وان البعوضـة

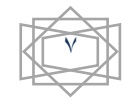


لو دخلت في أنفه اهلكته ولم يقدر على دفعها ، فاذا عرف هذه الامور حق المعرفة علم انه لا يليق به الافتخار بالقوة .

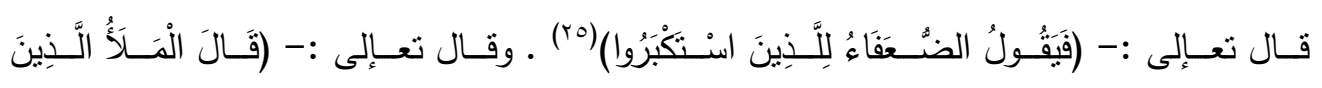

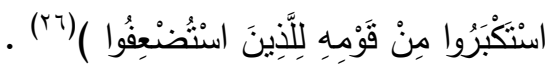

قابل المستكبرين بالضعفاء تتبيهاً ان استكبارهم كان بما لهم من القوة من البدن والمال . وهناك أمور أخرى تدعو الانسان إلى التكبر ، ولو دقق فيها لوجدها أمور زائلة ، فضلاً عن

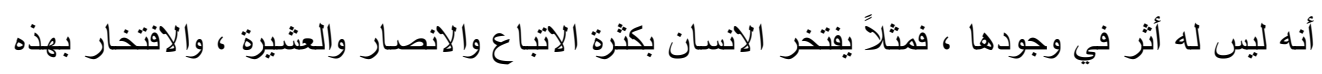

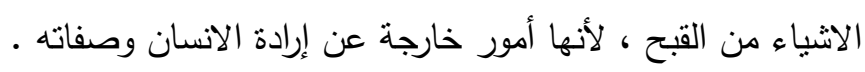

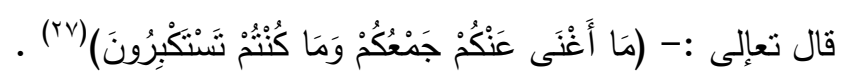

وقد ينشأ التكبر من بواعث العداء أو الحسد أو المباهاة ، مما يدفع المتصفين بهذه الصفات

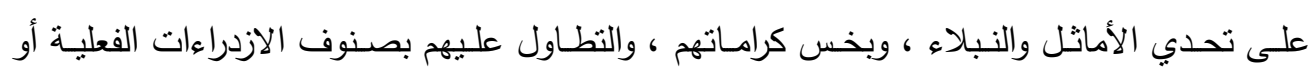
القولية ، كما يتجلى ذلك في تصرفات المتتافسين والمتحاسدين في المحافل والندوات(^؟) . . 
إن القرآن الكريم بأعنباره كتاب نتريعي واخلاقي رسم صورة خلاقة للإنسان الذي استخلفه

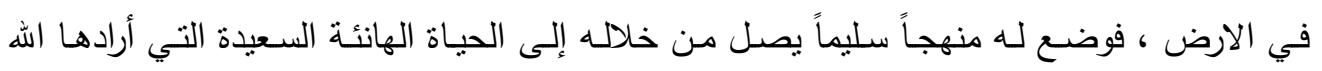

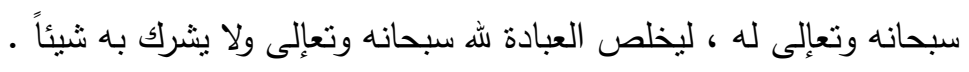

فوجهه إلى كثير من الاعمال والصفات الحسنة كالتواضع والصدق والامانة، ونهاه عن

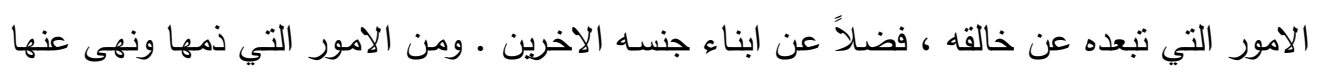
القران الكريم : التكبر ، فالتكبر من اعظم الصفات الذميمة في الاسلام ، وقد ورد في ذللك آيات كثيرة الآنداء

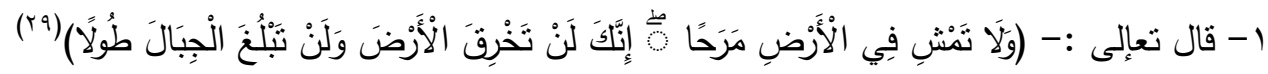

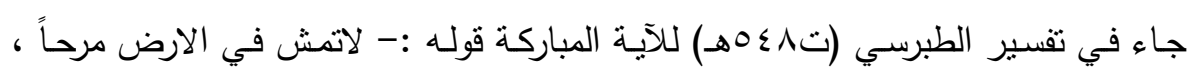

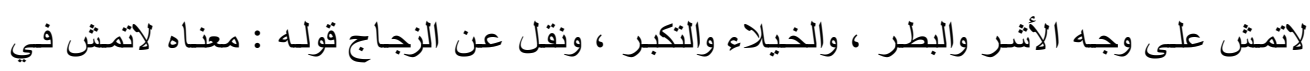

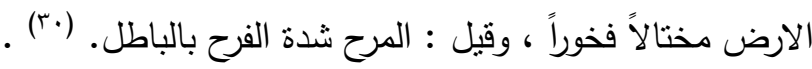

ولعل التقييد بالباطل للالالة على خروجه عن حد الأعتدال ، فان الفرح الحق هو مايكون

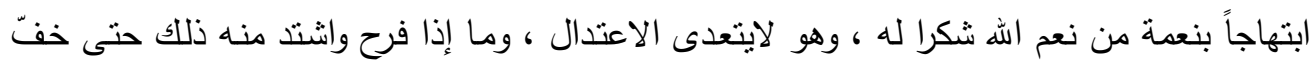

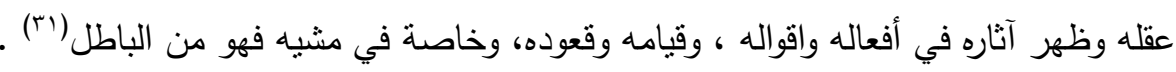
وانما ذكر المشي في الارض مرحاً ، لظهور ذلك فيه ، فان من مظاهر التكبر وصوره

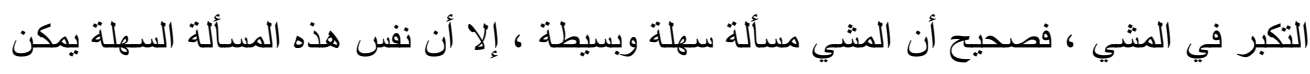

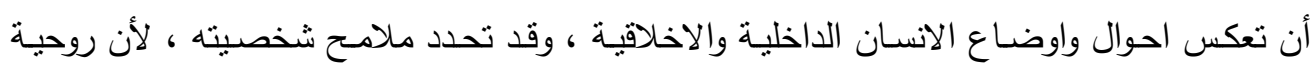

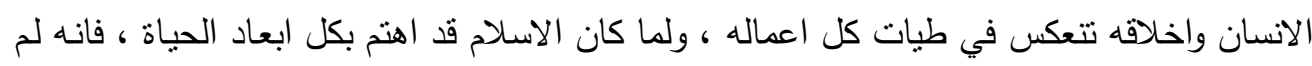
يهمل شيئا في هذا الباب ايضاً (rr).

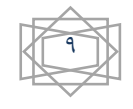


قال رسول الله (صلى الله عليه واله وسلم) قوله :- (من مشى على الارض إختيالا لعنته الارض ومن

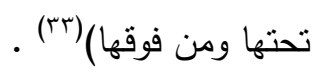

وقال (صلى الله عليه واله وسلم) ايضا :-- (من لبس ثوبا فاختال فيه خسف الله به من شفير جهنم ، وكان قرين قارون لانه اول من إختال)(זّ).

وجاء في كتاب مصباح الثريعة المنسوب للامام الصادق (عليه السلام) قوله :- (كن متفكراً في

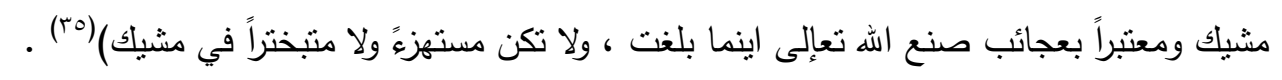

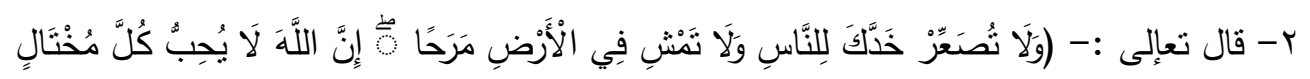
فَخَورِ (rT) الصعر : هو في ألاصل مرض يصيب البعير ، فيؤدي إلى إعوجاج رقبته .

قال الراغب الاصفهاني : ألصعر ميل في العنق ، والتصعير امالته عن النظر كثيرا، والمرح شدة

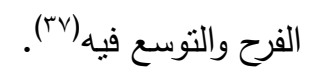

ومعنى الاية : أن لا تعرض بوجهاك عن الناس تكبرا ، ولا تمشِ في الارض مشية من اشتد

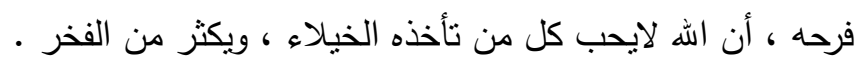

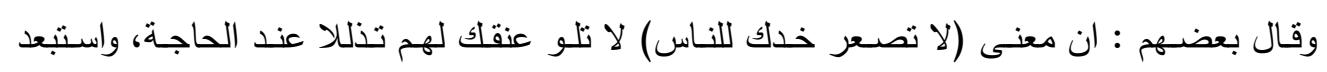

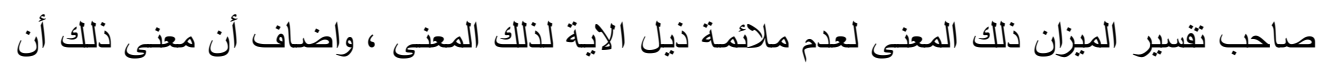
لاتمل وجهاك من الناس بكل ولا تعرض عمن يكلمك استخفافا به (^). وهذا المعنى قول ابن عباس ، أذ روى السيوطي (ت (19 (1) عهد قوله : (ولاتصعر خدلك للناس ، قال : هو الذي إذا سلم عليه لوى عنقه كالمستكبر)(

والمختال هو الثخص الذي برى نفسه عظيماً وكبيراً نتيجة سلسلة من التخيلات والاوهام . 


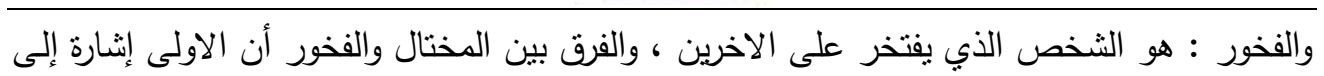

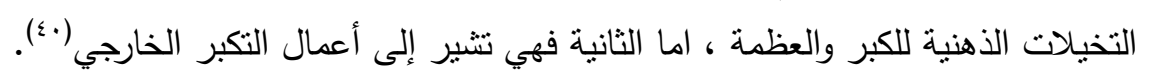
بمعنى أن الكبر ينقسم إلى ظاهر وباطن ، والباطن هو خلق في النفس ، والظاهر هو الجا

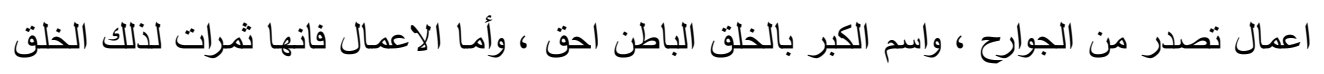

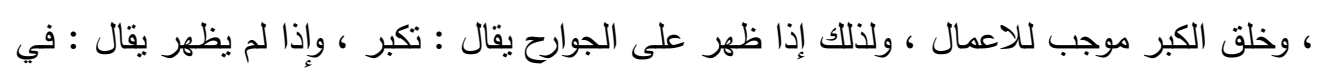

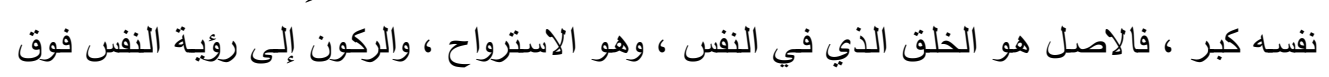

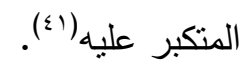

وعلى الرغم من هذا فان لقمان الحكيم يشير هنا إلى صفتين مذمومتين جداً ، وأساس توهين

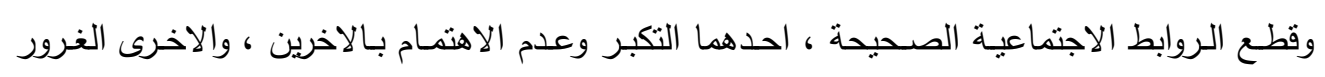

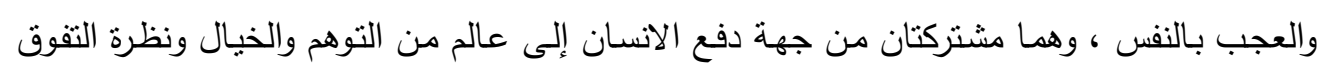
على الاخرين ، واسقاطه في الهاوية ، وبالتالي نقطعان علاقته بالاخرين وتعزلانه عنهم (rء).

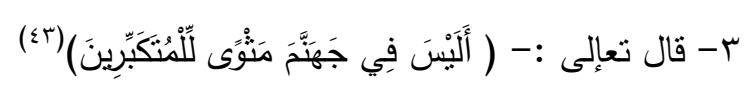

تنين الاية الكريمة عاقبة التكبر والمصير الذي انتهى إليه الهتكبرون ـ قال الثيخ الطوسي

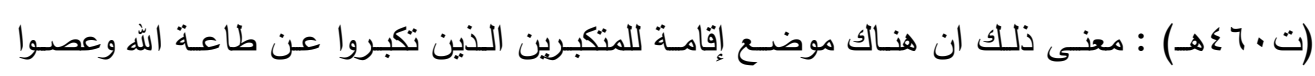
أوامرة(๕)

فالمتكبر أثند الناس عتواً وامتتاعـاً عن الحق والعدل ومقتضبات الثشرائع والاديان ـ قال

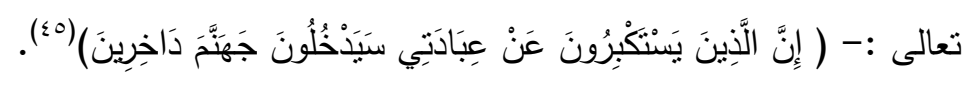

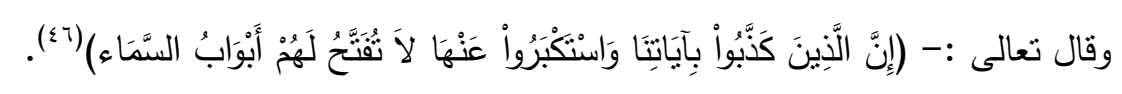
وقال الرسول (صلى اله عليه واله وسلم) :- (يحشر المتكبرون الجبارون يوم القيامة في صور الذر

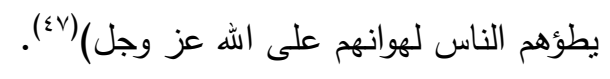




\section{العـــــــدد الثاني والعشرون}

\section{مجلــــة كليــــة التربيــــة}

وروى الكليني (توبr وسه) بسنده عن ابن بكير ، عن الامام الصادق (عليه السلام) قوله :- (إن في

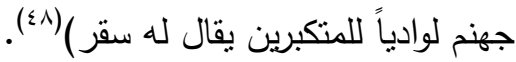

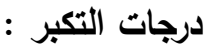

تبين لنا الايات الكريمة التي تتاولها البحث لبيان مفهوم التكبر وأسبابه ، وايات اخرى كثيرة أن التكبر باعتبار مصاديقه يكون على ثلاث درجات :

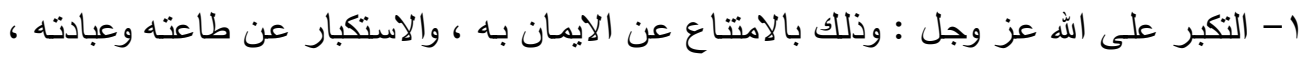

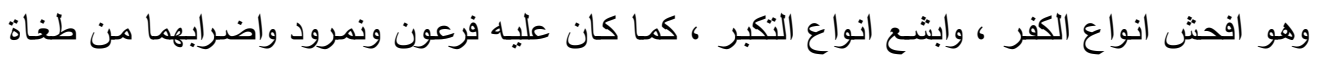

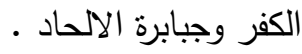

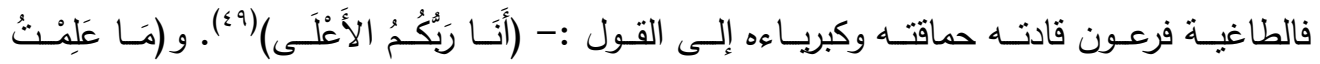

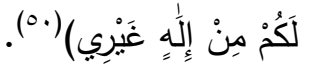
ونمرود الظالم اذ حاج ابراهيم (عليه السلام) في ربه ، فقال :- (أَنَا أُخْيِي وَأُمِيثُ)(10) . على العكس من ذلك فقد ضرب لنـا تبارك وتعالى في كتابـه الكريم مثناً رائعاً للذين لا

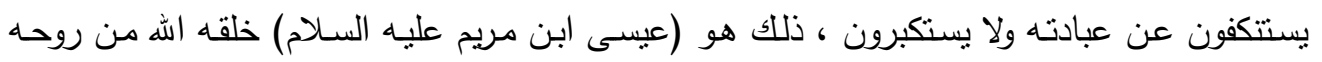

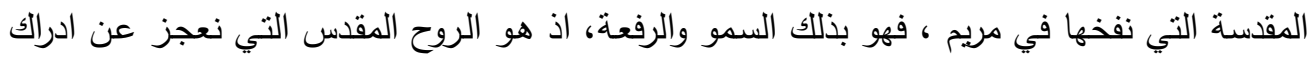

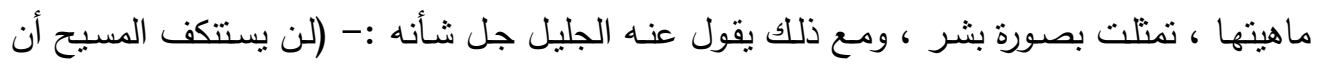

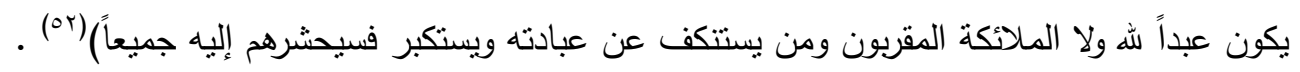
r- التكبر على الانبياء ، وذلك بالترفع عن تصديقهم والاذعان لهم ، كقولهم :- (أَنْؤمِنُ لِِبَتَرَيْنِ

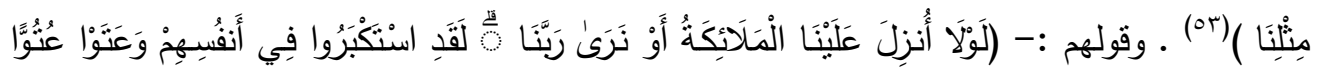

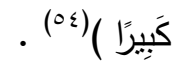
وهذا النوع من التكبر قريب من الأول وان كان دونه .

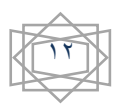




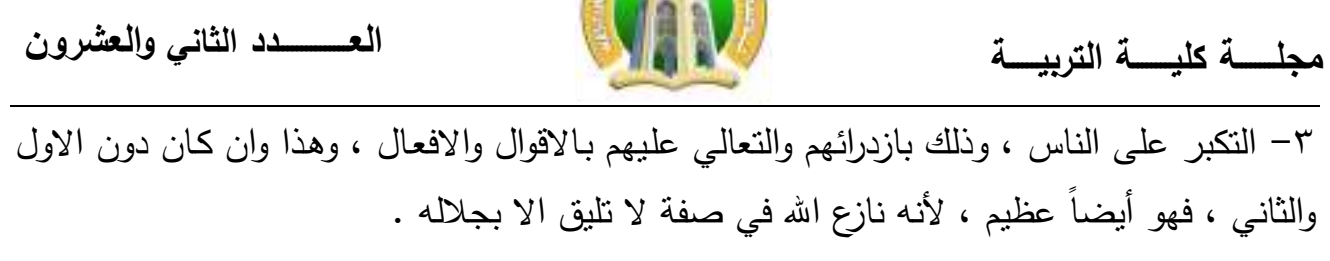

فالكبريـاء والعظمـة لله فقط ، لأنـه هو الغني بذاتـه ، لا طريـق للفقر والاحتيـاج إلى ذاته

المقدسة ، فهو الكمال المطلق وجميع الموجودات محتاجه اليه .

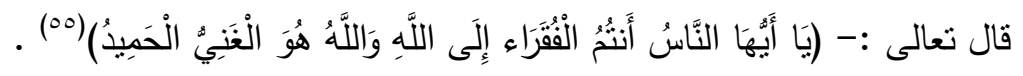


تعرف السنة باللغة : بأنها السيرة ، حسنة كانت أو قبيحة(ه) . وقيل هي الطريقة المعتادة ،

سواء أكانت حسنة ام سيئة ، كما في الحديث الصحيح :- (من سن في الاسلام سنة حسنة ، فله أجرها وأجر من عمل بها بعده من غير أن ينقص من اجورهم شيء ، ومن سن في الاسـام سنة

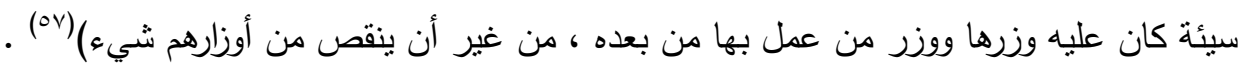
أما في اصطلاح الفقهاء ، فالسنة هي : قول النبي (صلى الله عليه واله وسلم) أو فعله أو تقريره ، وهي عند فقهاء الامامية : قول المعصوم أو فعله أو، تقريره(ه) .

لان لفظ العصمة هو القاسم المشترك بين النبي (صلى الله عليه واله وسلم) وال بيته (عليهم السلام) ، فالأئمة ليسوا من قبيل الرواة عن النبي (صلى الله عليه واله وسلم) والمحدثين عنه ، ليكون قولهم حجة دن جهة أنهم ثقات في الراوية ، بل لانهم هم المنصبون من الله تعالى على لسان النبي

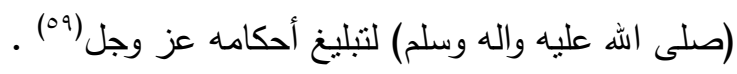

وبما أن السنة المطهرة هي صنو القران والثـارحة لله ، والمصدر الثاني للنشريع ، فقد كان الرسول (صلى الله عليه واله وسلم) بشخصه وشمائله وسلوكه وتعامله مع الناس ترجمة عملية بشرية حية لحقائق القرآن وتعاليمه وآدابه وتتريعاته ، ولما فيه من أسس تربوية اسلامية . لذلك تواترت الروايات الثريفة على ذم التكبر والنهي عنه ، بأعتباره من أعظم الصفات الذميمة في

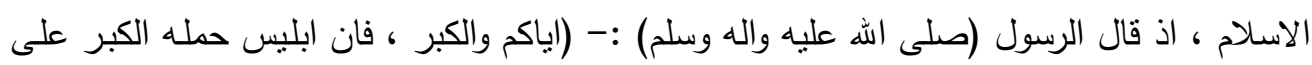

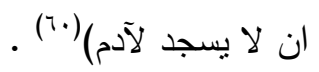

وقد أثنار ألامام علي (عليه السلام) إلى هذا المعنى في خطبة له ، فقال :- (فاعتبروا من

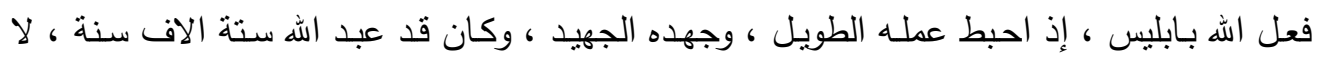
يدرى أمن سني الدنيا أم من سني الاخرة ، عن كبر ساعة واحدة ، فمن بعد ابليس يسلم على الله

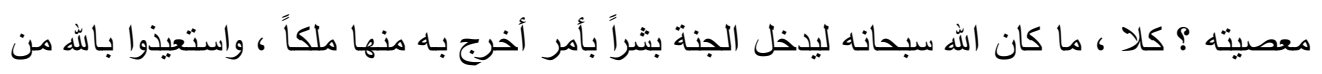




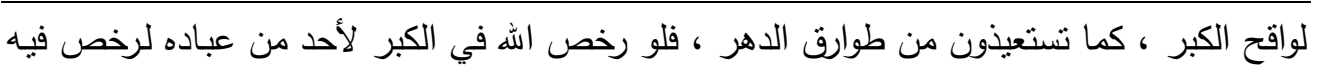

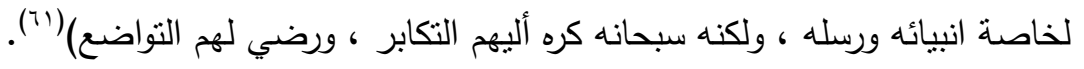

وقد سأل الامام الصادق (عليه السلام) ، عن أدنى الالحاد ، فقال :- (إن الكبر ادناه)(Tr).

وفي هذه الرواية نجد أن الامام (عليه السلام) لم يعد التكبر صفة ذميمة فحسب ، بل عده

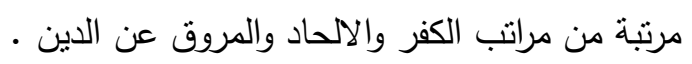

فالإحاد هو الميل عن الحق ، والمراد به إما نفي الصانع ، أو اثبات الثريك له ، أو ألأعم منهما . وروى الصدوق بسنده عن الامام الباقر (عليه السلام) قوله :- (الكبر مطايا النار)(זَ) .

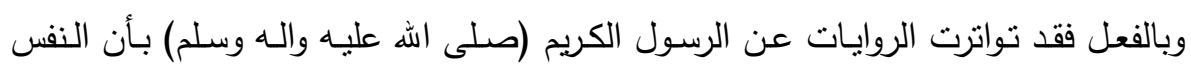

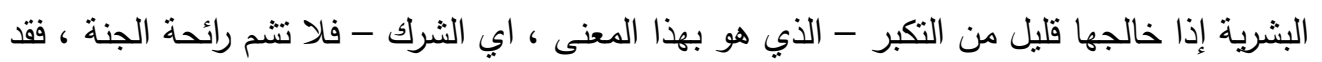

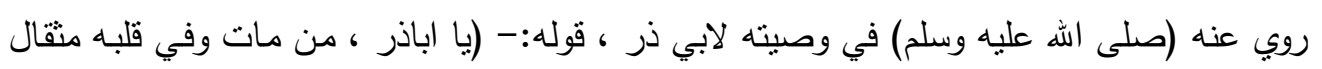

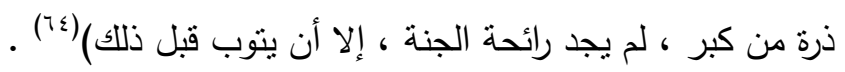

وروى مسلم في صحيحة ، عن عبد الله بن سعود ، قال : قال رسول الله (صلى الله عليه واله وسلم)

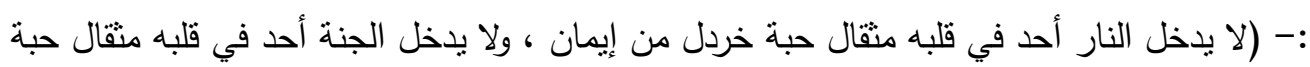

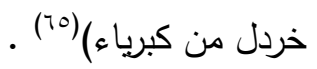

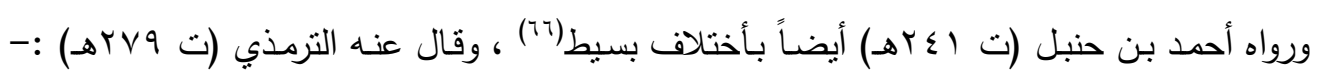

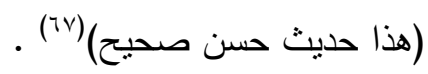

والكبر الذي أثشار إليه الحديث الثريف هو الجحود ، والأمتتاع عن قبول الحق ، لا أن

يتكبر الانسان على مخلوق مثله ، وهو مؤمن بربه .

فقد روى الكليني بسنده عن محمد بن مسلم عن (احدهما) - يعني الامام الباقر أو الصادق (عليهما

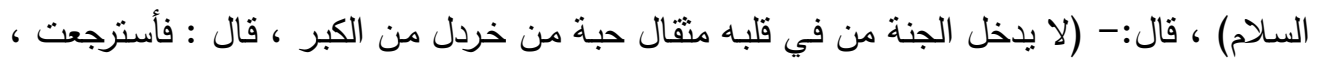

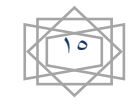


فقال : مالك تسترجع؟ قلت لما سمعت منك ، فقال: ليس حيث تذهب ، إنما أعني الجحود ، إنما هو

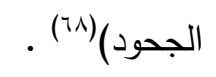

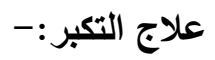

التكبر هذا الهوس الأخلاقي الخطير ، والمرض المهلك ، علاجه واقع تحت اختيار الانسان نفسه ، وعلاجه مركب من أجزاء علمية وعملية .

ا- العلمية :- وحاصلها أن يعرف الانسان نفسه وربه ، فأنه متى عرف نفسه حق المعرفة ، علم أنه

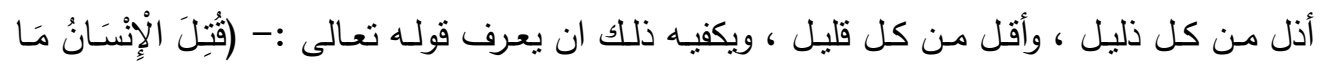

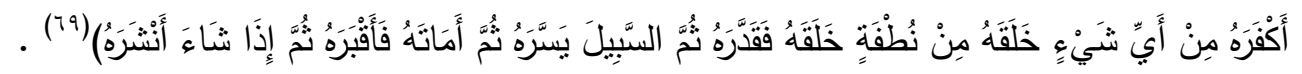
فالآيـة الكريمـة تبين واقع الأنسان وما يتصف بـه من ألوان الضعف والعجز ، فأوله نطفة قذرة ، وآخره جيفة منتتة ، وهو بينهما عاجز واهن ، فمن كان هذا حاله فمن اين لله البطر والكبرياء تياء ولهن

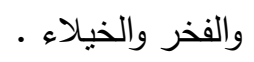

وروي عن الامـام الحسن (عليه السـلام) قوله :- (لا ينبغي لمن عرف عظمة الله أن يتعاظم ، فان

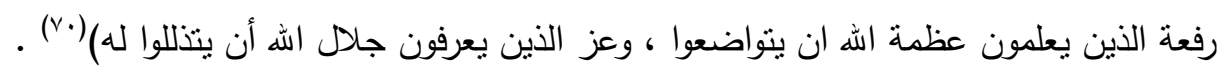

فاذا عرف الانسان حده ، وأدرك حقيقته ، وعرف ربه علم انه لا تليق العظمة والكبرياء إلّا به ، وأن كل ما سواه مقهور مغلوب عاجز لا وجود له إلّا بفيض وجوده ورحمته ، فهو لا بملك لنفسه

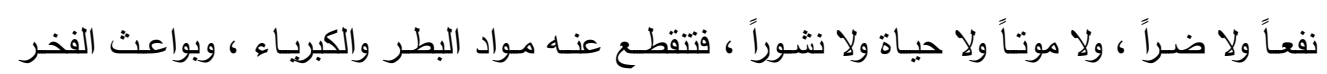
والخيلاء .

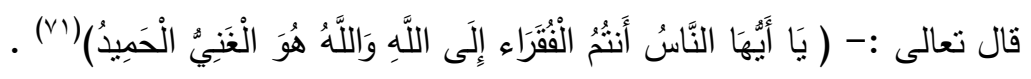
ץ- العملية :- امـا العلاج العملي ، فهو التواضـع لله بالفعل ، ولسائر الخلق بالمواظبة على أخلاق المتواضعين ، لتخفيف حدة التكبر في نفسه .

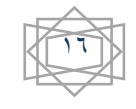


قـال الرسـول (صـلى الله عليـه والـه وسـلم) :- (تواضـعوا وجالسـوا المسـاكين تكونـوا مـن كبـراء الله

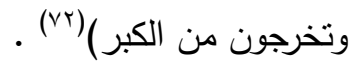

وقال (صلى الله عليه واله وسلم) أيضاً :- (ان أحبكم الي واقربكم مني يوم القيامة مجلساً ، احسنكم خلقاً واشدكم تواضعاً)(

فالتواضع من الصفات الحميدة ، والسجايا المفضلة في نظر الاسلام ، يجب على كل مسلم في اسلوب معاشترته مـ الاخرين أن لا يحذر من التكبر والاستعلاء ، بل عليه ان يكون منواضعاً بالنسبة إلى غيره ، ويحترم شخصيات الاخرين على اختلاف طبقاتهم ومنازلهم .

أما التواضع الله سبحانه وتعالى فيكون بالانشغال بأنواع العبادات والطاعات، والمداومة على ذكر الله ، والابتهال إليه والتضرع بين بديه ، وتفويض الامر إليه.

فالسجود لله سبحانه وتعالى يذهب بالكبر ، قال الرسول (صلى الله عليه وآله وسلم):- (من وضـع وجهه لله عز وجل فقد برئ من الكبر)(ع (V) .

وعن الزهراء (عليها السلام) ترويها زينب (عليها السلام) قالت :- (الصلاة تتزبهاً عن الكبر)(V0) . 


\section{الخاتمة}

الحمد لله الذي وفقنا لتسليط الضوء على ظاهرة اجتماعية خطيرة ، طالها كانت سبباً لهلاك

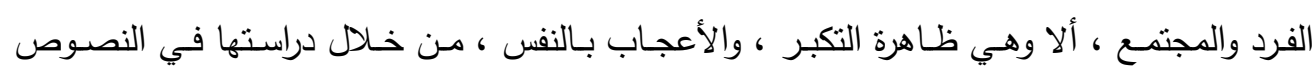

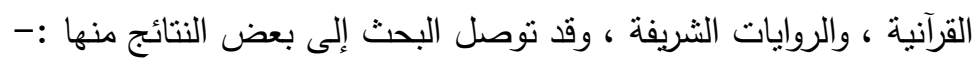

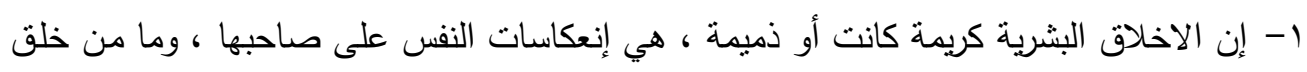

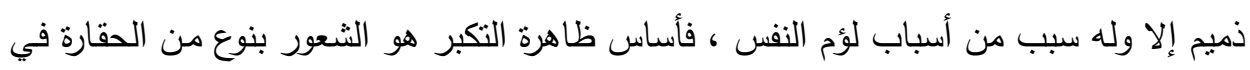

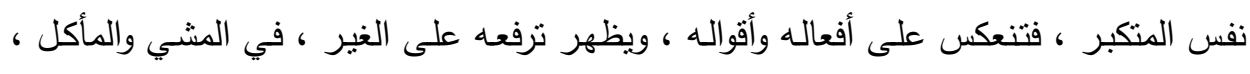

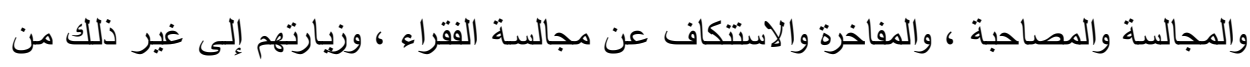
الافعال.

ץ- لا يختص التكبر بجنس معين من البشر ، فمن الممكن أن يظهر هذا الداء في الطبقات والامم

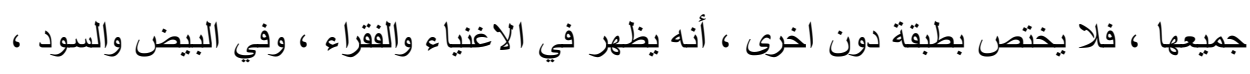

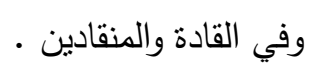

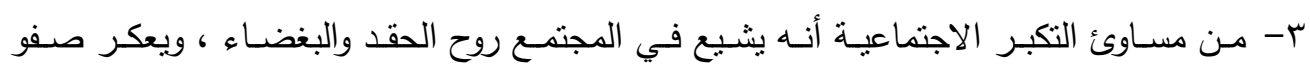

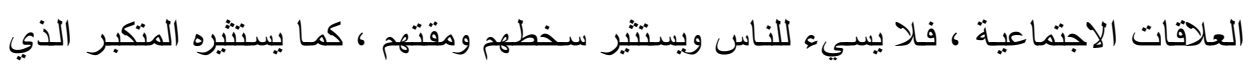

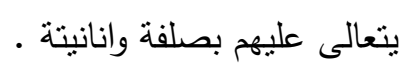

ع - ليس من التكبر أن يتحرى الانسان ويجتهد ، ليصير كبيرا بامكانياته وقدراته ، حتى يكون في

$$
\text { المكان الذي يجب أن يكون فيه وفق استحقاقه . }
$$

وكذلك ليس من التكبر أن بهنم الانسان بنفسه ، ويتمتع بالنعم الني اسبغها الله سبحانه وتعالى ، فيظهر ذلك في مسكنه وملبسه وراحلته ، لان الله سبحانه وتعالى يحب أن يرى اثر نعمه على بلى عباده.

ه- التكبر مرض من الممكن علاجه والتخلص منه إلى الابد ، والسبيل إلى ذلك يحتاج إلى معالجة

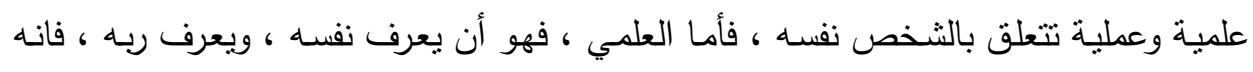

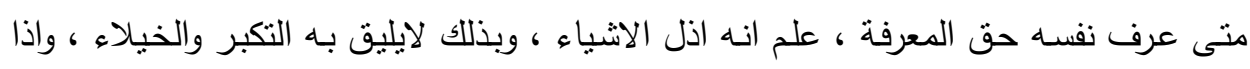

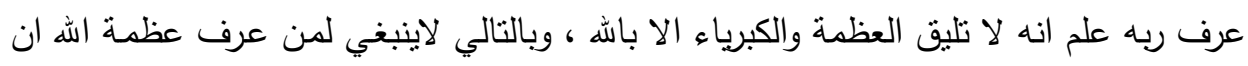

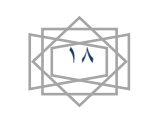


العـــــــدد الثاني والعشرون

مجلــــة كليـــــة التربيــــة

يتعـاظم ، فـان رفعـة الذين يعلمون عظمـة اله أن يتواضـعوا ، وهذا هو العـلاج العلمي القاطع • الاصل التكبر

أمـا العملي ، فهو التواضـع لله سبحانه وتعـالى ، وتفويض الامـر إليـه ، وحسـن المكالمـة والمجالسـة

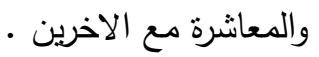

فالتواضع من الصفات الحميدة ، والسجايا المفضلة في نظر الاسلام ، فمن تواضع برئ من التكبر . 


\section{العـــــــد الثاني والعشرون}

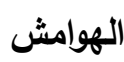

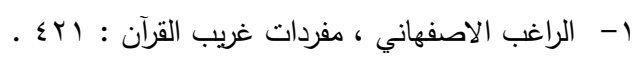

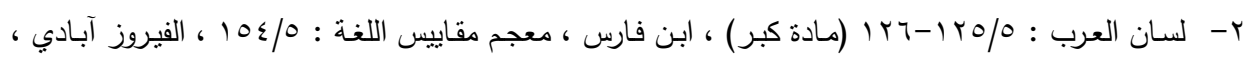

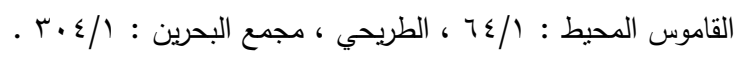

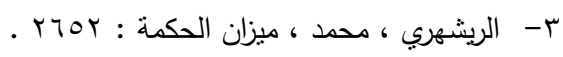

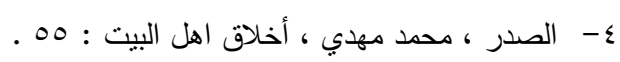

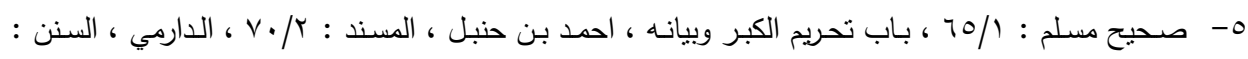

$$
\text { r rAr/l }
$$

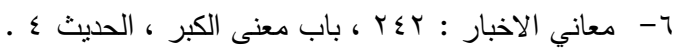

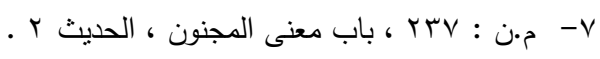

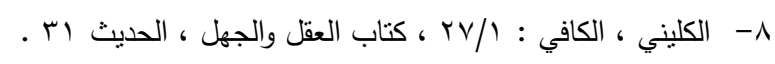

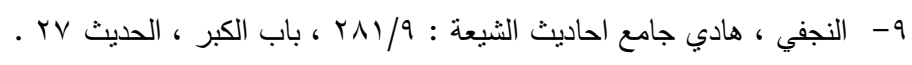

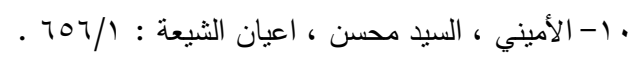

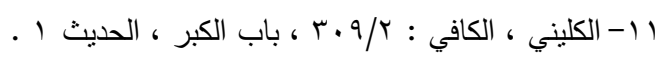

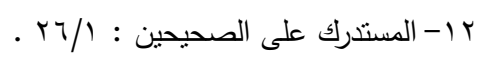

r

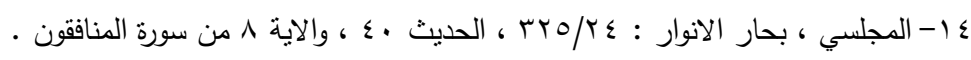

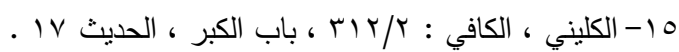

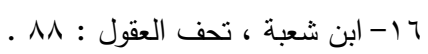

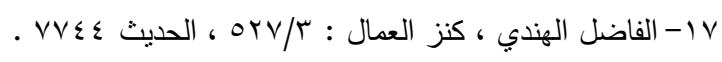

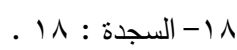

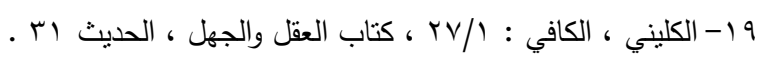

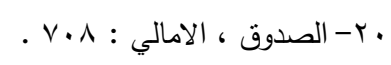

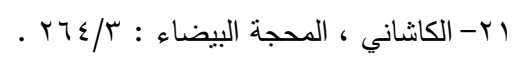

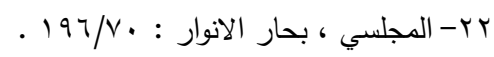

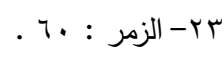

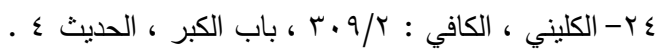

$$
\text { . . غ غ }
$$

. V0: :

. . : : الاعراف

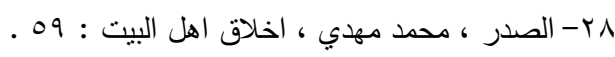




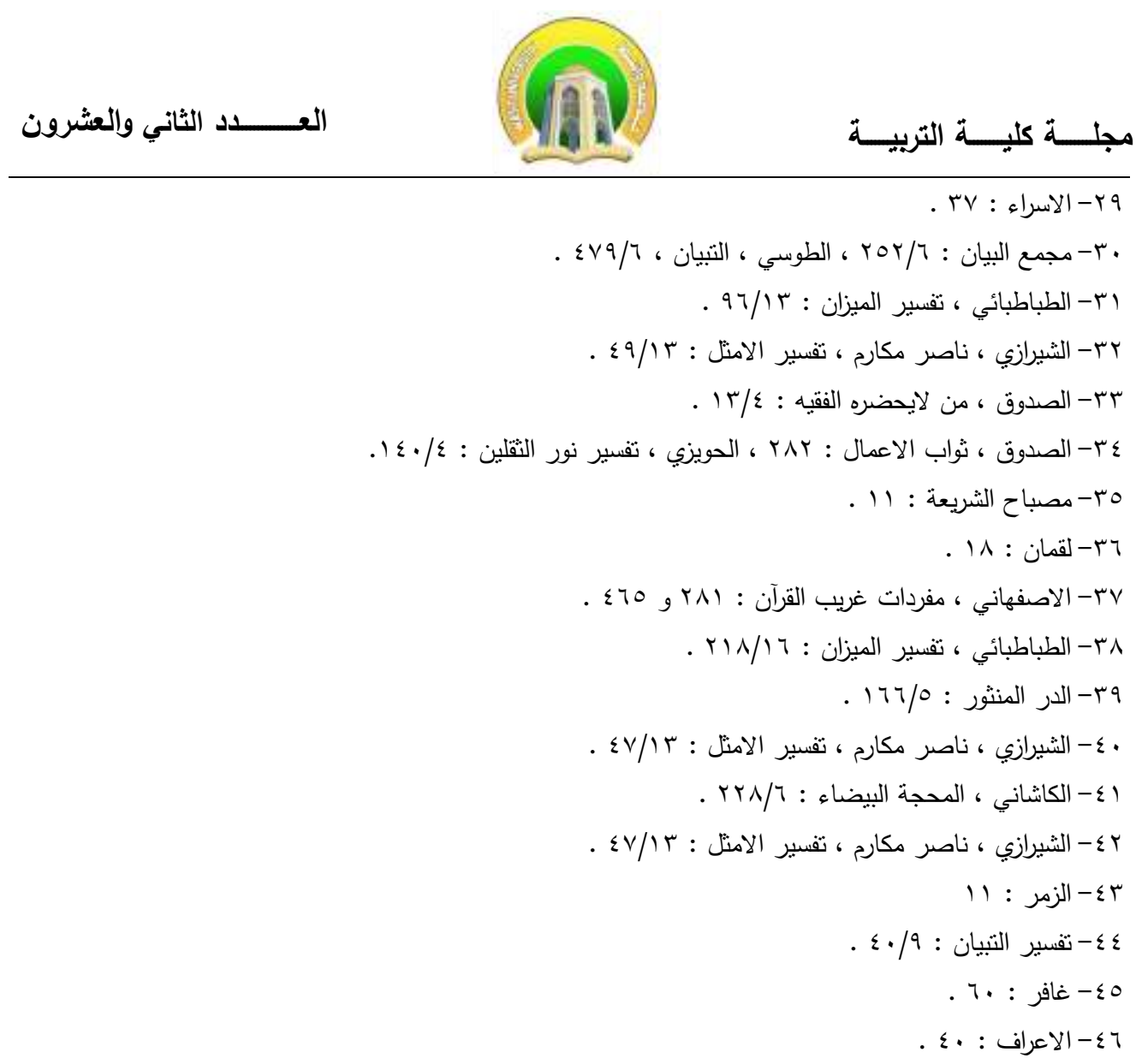

V \&

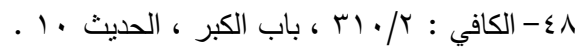

9

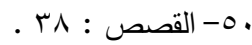

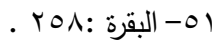

IVT: النساء

.

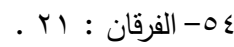

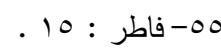

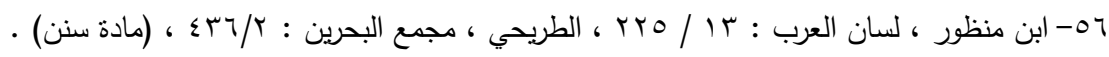

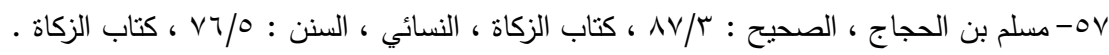

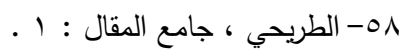

9 هـ الحكيم ، حسين عيسى ، مذاهب الاسلاميين في علوم الحديث : 10 ـ .

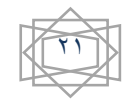




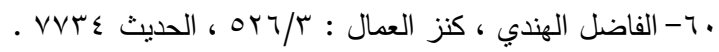

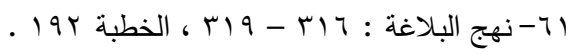

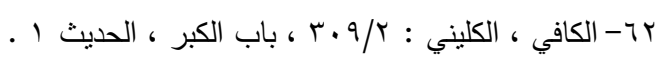

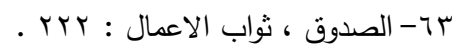

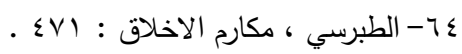

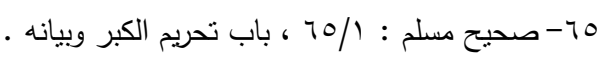

צ7- مسند احمد بن حنبل :

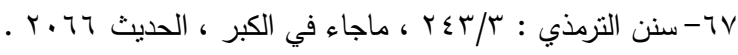

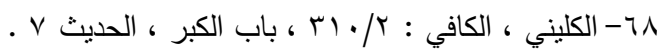

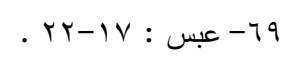

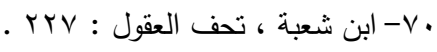

$$
\text { 1ابن }
$$

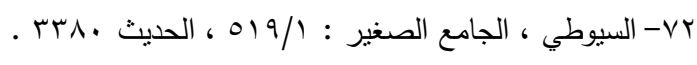

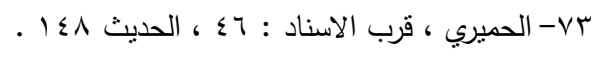

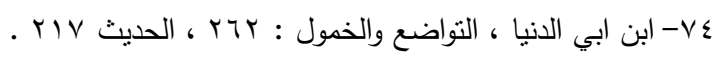

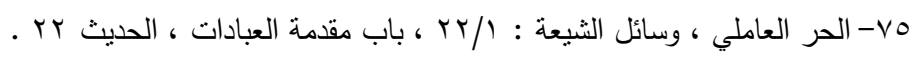

\section{المصادر}

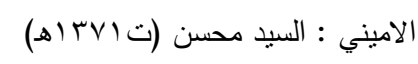

1- اعيان الثيعة ، تحقيق حسن الامين ، دار التعارف بيروت (ب.ت التان)

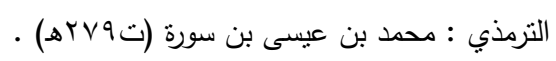

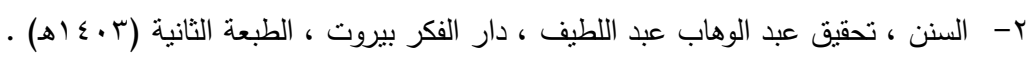

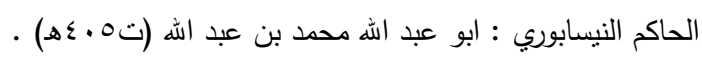

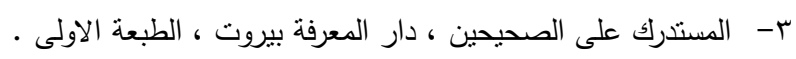

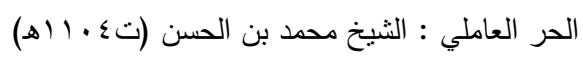

ع - وسائل الثيعة إلى تحصيل مسائل الثريعة ، تحقيق عبد الرحيم الثيرازي ، دار احياء التراث العربي ، بيروت .

الحكيم : حسن عيسى (الدكتور )

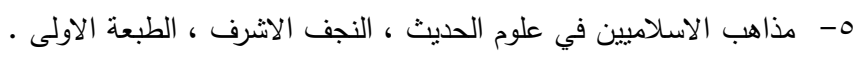

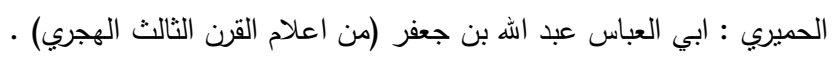

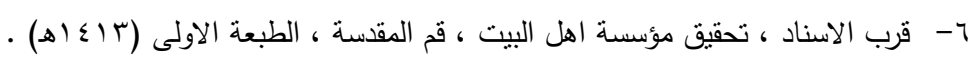

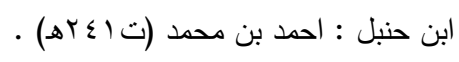

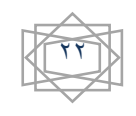




$$
\begin{aligned}
& \text { العـــــــد الثاني والعشرون }
\end{aligned}
$$

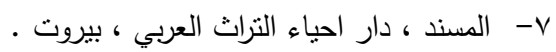

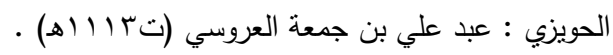

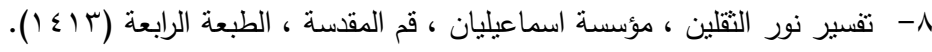

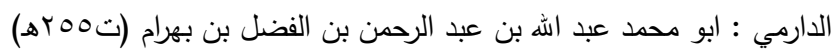

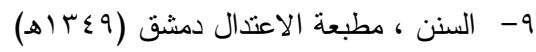

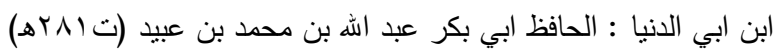

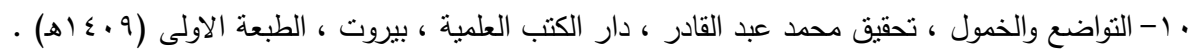

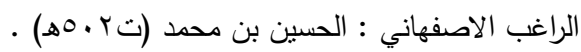

$$
\begin{aligned}
& \text { 1 1- مفردات غريب القرآن ، دفتر نشر الكتاب ايران ، الطبعة الثانية (ع ـــ اهـ). }
\end{aligned}
$$

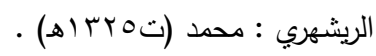

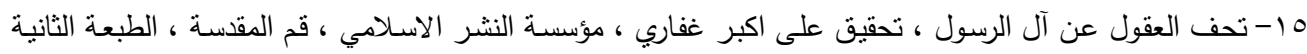

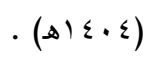

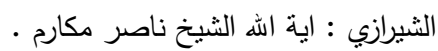

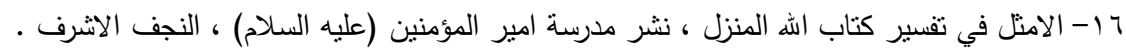

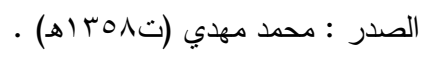

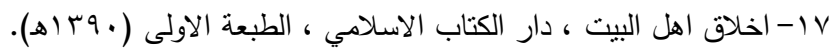

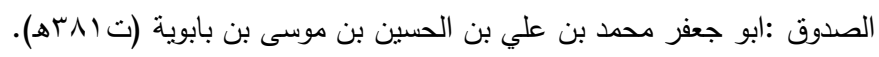

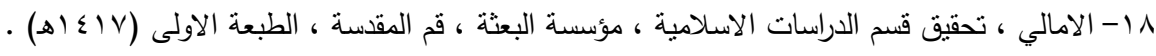

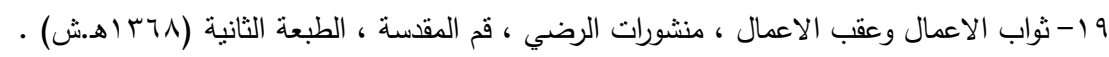

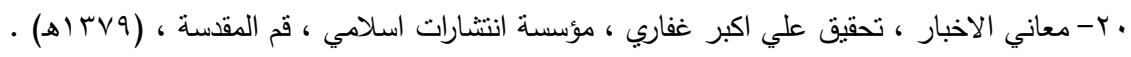

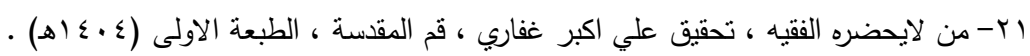

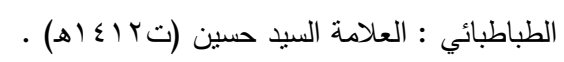

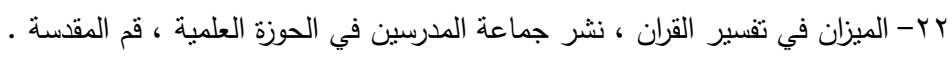

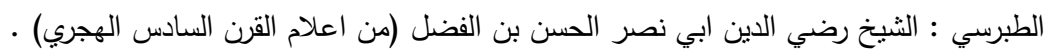

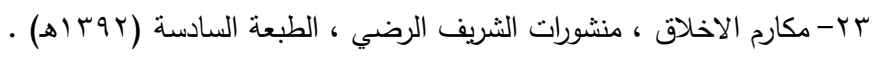

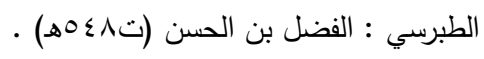




\section{العـــــــد الثاني والعشرون}

\section{مجلــــة كليــــة التربيـــــة}

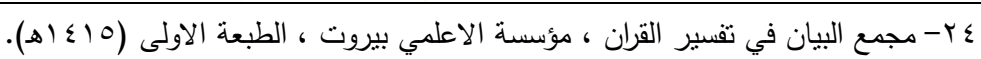

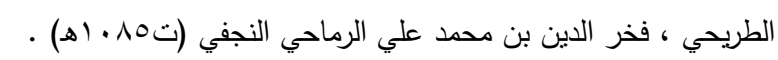

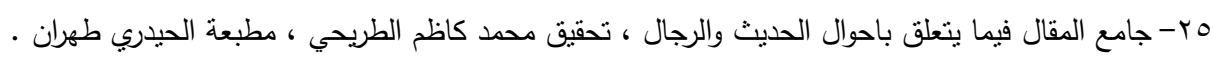

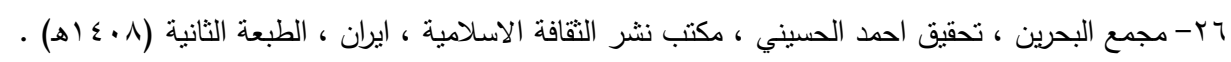

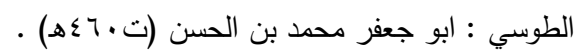

Vץ- التيبان في تفسير القرآن ، تحقيق احمد حيبب العـاملي ، دار احياء التراث العربي ، مكتب الاعـلام الاسـلامي . (ه) ( 9 ( 9$)$

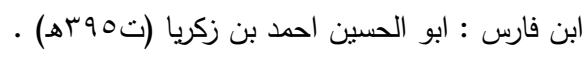

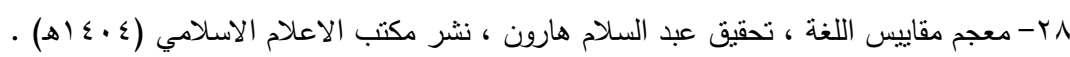

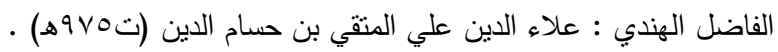

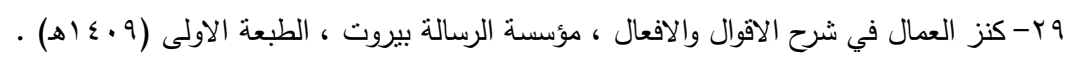

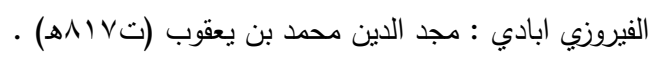

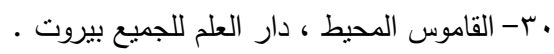

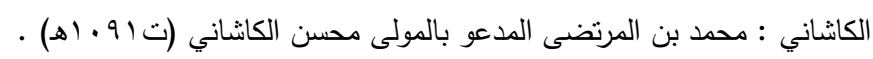

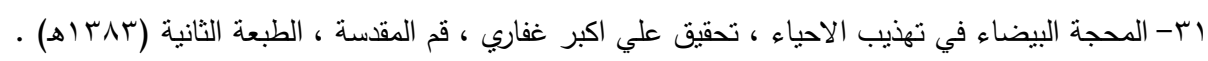

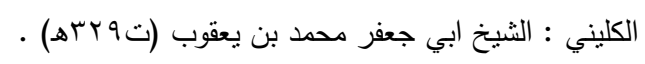

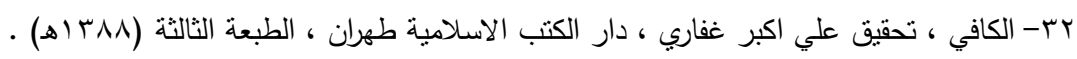

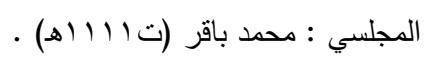

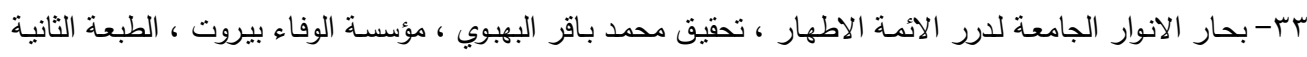

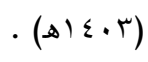

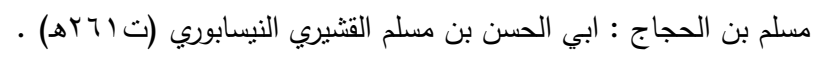

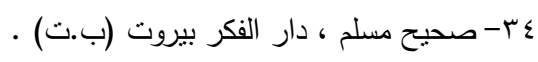

هب- مصباح الثريعة المنسوب للإمام الصادق (عليه السلام) ، مؤسسة الاعلمي بيروت ، الطبعة الاولى ( . . ـ اهـ) .

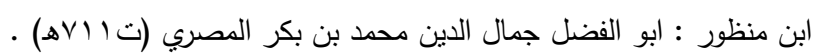

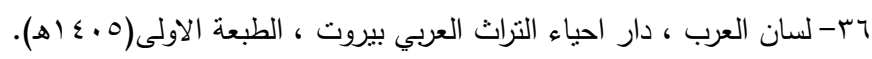

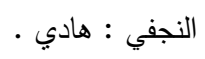

VT- موسوعة احاديث اهل البيت (عليهم السلام) ، دار احياء التراث العربي ، بيروت ، الطبعة الاولى (بr؟ اهـ) .

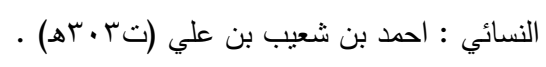

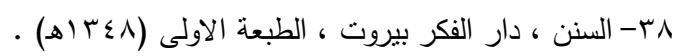

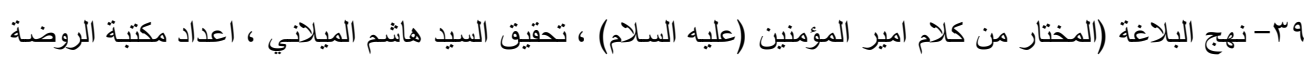

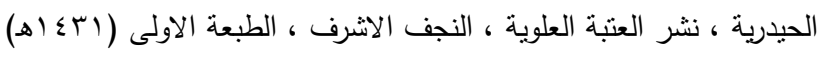

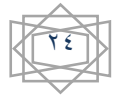

